\title{
Selenium \& Preeclampsia: A Global Perspective
}

Vanderlelie J \& Perkins AV

\author{
School of Medical Science \\ Griffith Health Institute, \\ Griffith University,
}

Southport, Queensland, Australia.

J.Vanderlelie@griffith.edu.au, A.Perkins@griffith.edu.au

Corresponding Author;

Dr Jessica Vanderlelie

J.Vanderlelie@griffith.edu.au

Ph: 61-7-55529161

Fax: 61-7-55528908

Key Words: Preeclampsia, Selenium, Global Nutrition. 


\begin{abstract}
Preeclampsia is a complex multisystem disorder of pregnancy where oxidative stress plays an important aetiological role. The role of selenium in the synthesis of endogenous antioxidants is well documented, and a significant reduction in selenium has been reported in preeclamptic women. The objective of this study was to map global selenium status and preeclampsia incidence.

This study identified peer reviewed journal articles reporting national preeclampsia incidence (\%) and matched these with reported values of selenium intake and plasma/serum selenium concentrations $(\mu \mathrm{g} / \mathrm{L})$. Matched data was obtained for 45 regions, reporting 6,456,570 births, spanning Europe, Asia, Australasia, Africa, North and South America. Increasing plasma selenium concentration was found to be correlated with a reduction in preeclampsia incidence (Pearson's $\mathrm{r}=$ $0.604, \mathrm{P}<0.0001)$. Countries with a reported serum/plasma selenium level of $\geq 95 \mu \mathrm{g} / \mathrm{L}$ were considered selenium sufficient and a significant reduction in preeclampsia incidence for countries above this value $(\mathrm{P}=0.0007)$ was noted. Significant reductions in preeclampsia incidence were found to coincide with increases in plasma/serum selenium concentration in the New Zealand $(\mathrm{P}=0.0003)$ and Finland $(0.0028)$ populations following Government intervention.

This study supports the hypothesis that selenium supplementation may be beneficial in reducing oxidative stress in women at risk of preeclampsia.
\end{abstract}




\section{Introduction}

Preeclampsia is a significant cause of maternal and perinatal mortality and morbidity, affecting an average of $3.45 \%$ of pregnancies globally [1]. Despite its prevalence, the exact causes of preeclampsia are still unclear; however, shallow trophoblast invasion and insufficient spiral artery remodelling are considered key early pre-clinical events that result in diminished placental perfusion and the generation of significantly increased levels of reactive oxygen species (ROS) within the preeclamptic placenta [2-4]. An imbalance between pro-oxidant ROS and endogenous antioxidant capacity is suggested as a possible factor in placental oxidative stress which results in increased trophoblast turnover and shedding of trophoblastic debris in to the maternal circulation [5-6]. There is an exacerbated maternal immune response leading to endothelial dysfunction and symptom manifestation in the preeclamptic patient [7-8].

Selenium is an essential trace element that is of significant importance to human health. A number of medical conditions have been associated with selenium deficiency [9] and there is increasing evidence to suggest that selenium deficiency may play a role in suboptimal cardiovascular [10], immune [11], and reproductive function [12-13]. The role of selenium is linked to its essentiality in the synthesis of numerous selenoproteins including the endogenous antioxidants Glutathione Peroxidase and Thioredoxin Reductase [9, 14], selenoproteins S, P and W and iodothyronine deiodinases [15]

Significant reductions in plasma [16-17] and toenail selenium [13] have been identified in preeclamptic patients, and coincide with observed reductions in endogenous antioxidant activity [8, 16] and increased levels of oxidative stress $[2-3,6,8]$ in preeclampsia. The role of selenium and endogenous antioxidant proteins in the development and progression of preeclampsia is gaining favour in line with the oxidative stress hypothesis. Furthermore, other selenoproteins which may be depleted in preeclampsia could impact on the development and progression of the syndrome.

Selenium is generally obtained through the diet and regional variations in intake have been correlated geographically with soil selenium concentration, geochemistry, and rainfall [18]. A number of regions have been identified as selenium deficient with artificial increases in selenium intake instituted through soil and livestock selenium supplementation, agronomic biofortification [19-20] and the importation of high selenium wheat [21]. When considering the importance of selenium in reproductive health, combined with noted reductions in daily intake and selenium status in the UK [22] and other European populations [9] the benefit of selenium supplementation for pregnant women is increasingly being considered. 
The current study aims to map the incidence of preeclampsia globally and match it to reported plasma and or serum selenium concentrations to further investigate the hypothesis that selenium supplementation during pregnancy may reduce the incidence of preeclampsia in populations with suboptimal dietary selenium intakes. 


\section{Experimental Methods}

We searched PubMed, ScienceDirect and the Cochrane Library with the search terms "preeclampsia" and "hypertension and pregnancy", and cross-referenced them with the terms “epidemiology" and "incidence". A total of 2149 peer-reviewed articles were identified from which we restricted our search to studies reporting incidence data for individual countries. We also used Google searches to gain access to published perinatal statistics for Australia and New Zealand.

The Preeclampsia Community Guideline (PRECOG) [23] definition of preeclampsia as new onset hypertension diastolic $\geq 90 \mathrm{mmHg}$ after 20 weeks gestation with new proteinuria determined as $\geq 1+$ $(0.3 \mathrm{~g} / \mathrm{L})$ on proteinuria dipstick testing, a protein/creatinine ratio of $30 \mathrm{mg} / \mathrm{mmol}$ or more on a random sample or a urine protein excretion of $300 \mathrm{mg}$ or more per 24 hours was used as the standard diagnostic criteria for report inclusion in the current study.

Preeclampsia incidence data was then matched to peer-reviewed articles reporting daily selenium intakes and serum or plasma selenium concentration by country. We searched PubMed and Science Direct data bases using the search terms "selenium", "daily intake selenium", "serum selenium" and "plasma selenium concentration" and cross-referenced this to countries with reported preeclampsia incidence as identified in the previous search. We also searched the reference lists of articles identified by these search strategies and selected those that reported selenium concentration or intake. When multiple reports were found listing preeclampsia incidence or selenium data for a single country, results were combined to produce a weighted average value. If the study presented data for a particular region within a country we attempted to match this with reported selenium concentrations for the same region to exclude regional variations in selenium concentrations where possible. Reported values for daily selenium intakes were noted from papers that utilised both estimations from blood concentrations and dietary analyses and are presented together as estimated daily intakes.

Matched data was analysed using Predictive Analysis SoftWare (PASW) Statistics version 18.0.2 (SPSS Inc., an IBM Company, Chicago, USA). A two-sided Pearson analysis was used to determine any possible correlation between serum/plasma selenium concentration and reported incidence of preeclampsia in a global context. Further analysis of the data was performed using a two-tailed t-test after splitting the data set on the basis of a plasma selenium concentration of 95 $\mu \mathrm{g} / \mathrm{L}$ that is considered indicative of maximal Glutathione Peroxidase activity [24]. Further analysis of the effect of increasing plasma selenium on the incidence of preeclampsia in the Finnish and New Zealand populations was also conducted using a two-tailed t-test. For all analyses a $\mathrm{P}$ value of 
less than 0.05 was considered significant with figures reported as mean \pm standard error of the mean (SEM). 


\section{Results}

Matched preeclampsia and plasma selenium data was collected for 45 regions globally, spanning 35 countries from Asia, Europe, Africa, Australasia, North and South America. Data was ranked according to increasing serum/plasma selenium concentration and presented in Table 1. A total of $6,456,570$ births were recorded in the preeclampsia studies reporting 222,812 preeclamptic births and a combined global preeclampsia incidence of $3.45 \%$ for the data set.

\begin{tabular}{|c|c|c|c|c|c|}
\hline Country & $\begin{array}{c}\text { Plasma } \\
\text { Selenium } \\
(\mu \mathrm{g} / \mathrm{L})\end{array}$ & $\begin{array}{c}\text { Estimated } \\
\text { daily selenium } \\
\text { intake }(\mu \mathrm{g} / \text { day })\end{array}$ & PET (\%) & $\mathbf{n}$ & Reference \\
\hline Egypt & 46.9 & 49 & 9.2 & 3162 & [25-27] \\
\hline Nigeria & 63.5 & - & 4.50 & 3926 & [28-30] \\
\hline New Zealand (Pre 1983) & 53.9 & $27.4^{*}$ & $6.65^{*}$ & 10484 & {$[31-41]$} \\
\hline Greece & 65.5 & $110-220$ & 2.30 & 9915 & [42-47] \\
\hline Croatia & 66.8 & 27.3 & 4.10 & 14003 & {$[48-50]$} \\
\hline Finland (pre 1985) & 67.6 & $25-60$ & $6.16^{*}$ & 1025339 & [51-66] \\
\hline Poland & 68.3 & $30-40$ & 4.40 & 4648 & {$[43,67-73]$} \\
\hline Brazil & 72 & 26.3 & 7.50 & 4892 & [74-76] \\
\hline Italy & 72.8 & 43 & 3.75 & 8894 & {$[44,77-84]$} \\
\hline India & 73 & $28-105$ & 4.18 & 29562 & [85-90] \\
\hline Denmark (1978-1983) & 75.5 & $38-47$ & 3.46 & 17457 & {$[43,91-95]$} \\
\hline Ireland & 77.2 & $44-51$ & 2.20 & 1048 & [96-100] \\
\hline Hungary & 77.4 & $41-90$ & 3.05 & 36642 & [101-105] \\
\hline Iran - Tabriz & 79 & - & 5.75 & 400 & [106-108] \\
\hline UK (1995-2005) & 79.1 & $29-39$ & 1.97 & 8366 & {$[44,109-112]$} \\
\hline Spain & 82.3 & 32 & 2.85 & 8295 & {$[44,113-114]$} \\
\hline
\end{tabular}




\begin{tabular}{|c|c|c|c|c|c|}
\hline Sweden (1987-1993) & 85 & 38 & $5.2^{*}$ & 10659 & {$[43,53,115-120]$} \\
\hline Germany & 86 & $38-48$ & 2.6 & 352698 & {$[121-124]$} \\
\hline Jamaica & 86 & - & 4.60 & 6275 & {$[125-126]$} \\
\hline Belgium & 90 & $28-61$ & 5.80 & 274 & {$[127-131]$} \\
\hline Scotland & 91 & 34.3 & 4.1 & 9057 & {$[132-137]$} \\
\hline Denmark (1996-2002) & 94.2 & 68 & $2.22 *$ & 81708 & {$[44,138-145]$} \\
\hline China- Shanghai & 96.2 & $53-80$ & 3.90 & 16936 & {$[146-148]$} \\
\hline Australia & 96.7 & $55-87$ & 3.2 & 208879 & {$[20,149-151]$} \\
\hline Sweden (1992-2006) & 97.6 & 38 & $2.9 *$ & 838528 & {$[44,152-156]$} \\
\hline Mexico & 100 & $61-73$ & 5.50 & 41828 & [157-159] \\
\hline USA - NY & 100.9 & 81 & $3.3^{*}$ & 703457 & [160-169] \\
\hline Netherlands & 102 & 72 & 1.4 & 2413 & {$[43-44,53,170-173]$} \\
\hline Portugal & 102 & $10-100$ & 1.40 & 6276 & {$[43,174-175]$} \\
\hline Saudi Arabia & 103 & $75-122$ & 2.80 & 705 & {$[176-178]$} \\
\hline Finland (post 1985) & 106.6 & $67-110$ & $1.96^{*}$ & 9216 & {$[53,58,140,179-188]$} \\
\hline New Zealand (post 1983) & 113 & $19-80$ & $1.94^{*}$ & 330998 & {$[21,24,189-202]$} \\
\hline Norway & 113.5 & 77 & $3.01 *$ & 1979859 & {$[56,203-214]$} \\
\hline Canada - Ontario & 115 & $98-224$ & 3 & 386323 & {$[215-220]$} \\
\hline Israel & 119 & 77.3 & 2.8 & 82436 & [221-222] \\
\hline Singapore & 119 & - & 3.6 & 2213 & {$[223-225]$} \\
\hline Iran - Jahrom & 119 & - & 3.3 & 2300 & {$[108,226]$} \\
\hline UK (1970-1988) & 120 & 60 & 3.1 & 15744 & {$[43,47,227-234]$} \\
\hline
\end{tabular}




$\begin{array}{lccccc}\text { USA - MA } & 121 & 60-220 & 3.7 & 1096 & {[121,235-238]} \\ \text { Japan } & 122 & 19-180 & 1.7 & 11311 & {[239-243]} \\ \text { Iran - Mashhad } & 122.7 & - & 3.6 & 83 & {[244-247]} \\ \text { Canada - Alberta } & 123.5 & 98-224 & 1.7 & 97270 & {[215-216,248-249]} \\ \text { Canada - Montreal } & 146 & 98-224 & 2.2 & 5337 & {[215-216,250-252]} \\ \text { Thailand } & 146 & 27-75 & 1.9 & 35923 & {[159,253-254]} \\ \text { Taiwan } & 153.2 & 145.2 & 1.4 & 29735 & {[255-257]}\end{array}$

Table 1. Global incidence of preeclampsia matched to reported plasma selenium concentration.

*Denote multiple reported values were utilised to calculate an average for the country. $\mathrm{n}$ value represents patients in studies reporting incidence of preeclampsia.

PET \% : Preeclampsia incidence represented as a percentage

Pearson correlation analysis demonstrated a significant correlation $(\mathrm{P}<0.0001)$ between increasing plasma selenium concentration and decreasing incidence of preeclampsia (Pearson $r=-0.604,95 \%$ $\mathrm{CI}=-0.377$ to -0.462 ). This correlation is illustrated in Figure 1 with associated linear trend and $95 \%$ CI lines $\left(\mathrm{R}^{2}=0.365\right)$.

Activity of antioxidant seleno-enzymes is correlated to increasing selenium concentration both in cell culture and in animal [258-259] and human systems [35]. Plasma concentrations of approximately 95 (range 89-114) $\mu \mathrm{g} / \mathrm{L}$ are considered adequate to maximise the activity of the endogenous antioxidant Glutathione Peroxidase [24, 260], however a plateau in Glutathione Peroxidase activity is not seen until plasma levels of $140 \mu \mathrm{g} / \mathrm{L}$ are reached [260]. In light of this information we split the data set into two groups using a plasma selenium concentration of $>95$ $\mu \mathrm{g} / \mathrm{L}$ as indicative of seleno-sufficiency (Figure 2). By this criterion, 23 countries considered seleno-sufficient had a combined reported incidence of preeclampsia of $2.75 \%$ (SEM 0.210) that upon unpaired two sided t-test analysis was found to be significantly lower $(\mathrm{p}<0.0007)$ than the selenium deficient subset $(n=22)$ with a mean reported incidence of $4.39 \%$ (SEM 0.407).

A number of regions globally have been identified as having low soil selenium concentrations however it was not until the 1970s that health authorities around the world became concerned when 
comparing daily intakes with those of the USA. In response to recognised deficiencies of selenium in the Finland population the Finnish government instituted compulsory soil selenium supplementation through fertilisation for cereal and grassland crops in 1985 and a significant increase in selenium status was achieved in the population [261-262]. New Zealand is also recognised as having low soil selenium and the population was recorded as having daily intakes similar to those in Finland [263]. In response, New Zealand took a more conservative approach and encouraged the supplementation of selenium in animal feeds in regions noted as deficient. Improvements in livestock selenium concentrations in combination with the deregulation of the importation of wheat from Australia and the USA and the increased availability of selenium-rich cereal products $[21,191]$ resulted in a significant increase in the selenium status of the New Zealand population [21].

To date the effect of increasing selenium supplementation on the incidence of preeclampsia in either population has not been reported. Reported statistics for each country were analysed pre and post selenium supplementation (Figure 3) and upon unpaired two-tailed t-test demonstrated significant reductions in the reported incidence of preeclampsia in both the New Zealand $(\mathrm{P}=0.0003)$ and Finland $(\mathrm{P}=0.0028)$ populations.

Finland was successful in reducing the incidence of preeclampsia by $61 \%$ from $5.24 \%$ prior to 1985 to $2.06 \%$ post selenium supplementation whereas a New Zealand noted a $71 \%$ reduction in the incidence of preeclampsia from $6.65 \%$ prior to supplementation in 1983 to $1.94 \%$ for the period 1985-2009. Interestingly the incidence of preeclampsia reduced to a similar level in both populations. 


\section{Discussion}

Selenium is an essential micronutrient which has well documented benefits to both male and female reproductive health. For males, selenium is important for testosterone biosynthesis and the production and development of normal spermatozoa [264]. In females decreased concentrations of selenium have been linked to compromised fertility and early pregnancy loss in both animals [265] and humans [12]. There have been several reports of decreased selenium status in mothers presenting with preeclampsia including significant reductions in toenail [13] and plasma selenium concentrations [16-17]. There have also been reports of decreased selenoprotein production in preeclamptic pregnancy including important endogenous antioxidants, such as glutathione peroxidase and thioredoxin reductase $[8,16]$. Given the importance of selenium in reproductive function this study investigated the nutritional selenium status of various populations and related that to the incidence of preeclampsia.

Geographical variations in soil selenium concentration are well documented and known to relate to plasma selenium concentrations regionally and within populations as demonstrated in the Iranian population where individuals in the North West of the country (Tabriz [106]) have lower selenium levels than those occupying the North Eastern (Mashhad [245-247]) and Southern (Jahrom [108]) regions of the country. Acknowledgement of the importance of selenium to human health, particularly cardiovascular disease and cancer prevention, sparked increased interest in population wide selenium status across the globe in the 1970s. Two key studies conducted in China [266] and New Zealand [267] provided the scientific basis for the establishment of recommended dietary allowances/intakes for females published in the United States (55 $\mu \mathrm{g} / \mathrm{day})$ [268], United Kingdom (60 $\mu \mathrm{g} /$ day) [269] and Australia (60 $\mu \mathrm{g} /$ day) [270]. There is a suggestion however that a conservative interpretation of the data was used [268] and that recalculation would suggest a much higher daily intake of $73 \mu \mathrm{g} /$ day would be necessary to achieve a plateau in plasma Glutathione Peroxidase activity [9], a widely accepted biomarker of selenium status. A further increase to 80$100 \mu \mathrm{g} /$ day would be needed if platelet saturation was considered as a measure of sufficiency [271]. The increased requirement of selenium during pregnancy and lactation is not under debate and all published RDI's recommend an increase in daily selenium intake by $10 \mu \mathrm{g} /$ day during pregnancy and $15 \mu \mathrm{g} /$ day during lactation to support the increased requirements of the fetus and newborn [122, 272-273]. The results of this study and those of others that have examined daily selenium intakes in various populations $[9,274]$ would suggest that a number of countries are consuming selenium at a suboptimal level and that during pregnancy, intakes are not high enough to maximise endogenous antioxidant activity. 
Evidence relating to regional variations in preeclampsia incidence and underlying selenium status is sparse and in some respects not entirely validated. However, a 1990 study from China reported an increased incidence of pregnancy induced hypertension in a region of the country known to be selenium deficient [275]. The current analysis of 70 studies reporting preeclampsia incidence and of 166 studies reporting plasma and or serum selenium concentrations summarises the global incidence of preeclampsia as it relates to selenium status. A significant correlation $(\mathrm{P}<0.0001$, Pearsons $\left.r=-0.604,95 \% \mathrm{CI}=-0.377,-0.762, \mathrm{R}^{2}=0.365\right)$ was found suggesting increasing selenium status may be beneficial in reducing the incidence of preeclampsia particularly when plasma concentrations exceed the level considered necessary to achieve optimal Glutathione Peroxidase activity $(95 \mu \mathrm{g} / \mathrm{L})$.

The routine supplementation of selenium in New Zealand and Finland provides an important example of direct intervention in the food chain. Both these countries have been successful in increasing the selenium status of residents above the $95 \mu \mathrm{g} / \mathrm{L}$ level and the current analysis demonstrated an associated significant reduction in the reported incidence of preeclampsia (Figure 3). The scenario in neighbouring European countries differs in terms of preeclampsia incidence with an increasing incidence seen in Norway [58] (3.3\% in 1970 to $4.5 \%$ in 2005) and the Netherlands (1.4\% in 1992-1994 [171] to 3.5\% in 2003-2004 [170]) and reductions in Denmark (3.5\% in 19781983 [92] to $2.2 \%$ in 1996-2002 [138-139, 145]) and Sweden (5.2\% in 1987-1992 [115] to 2.9\% in 1992-1996 [152]). When changes in selenium for these countries over similar time period was recorded it was found that the daily intake or serum level of selenium was found to increase in those countries noting reductions in incidence of preeclampsia (Denmark; $78.5 \mu \mathrm{g} / \mathrm{L}[43,93]$ to $94.2 \mu \mathrm{g} / \mathrm{L}$ [141-144] and Sweden; $85 \mu \mathrm{g} / \mathrm{L}[43,116-119]$ to $97 \mu \mathrm{g} / \mathrm{L}[44,155-156])$ and decreased in those countries with increased incidence of preeclampsia (Netherlands; $72 \mu \mathrm{g} / \mathrm{day}$ [173] to $49 \mu \mathrm{g} / \mathrm{day}$ [140]). Although it may be interesting to speculate that the reduction in the incidence of preeclampsia noted in this study may be related to increasing selenium status, this result does not prove cause and effect as multiple factors are likely to play a role in the development and incidence of this complex disease on a population wide level. In addition, the incidence of other diseases such as cardiovascular disease [276] and some cancers [277] has similarly declined over the past 25 years with improvements in surveillance and provision of improved clinical care.

Routine utilisation of selenium-based fertilisers and food fortification has been demonstrated to increase population based selenium status; however dietary differences between individuals will result in variable intakes within a population. In addition concern surrounds mandatory supplementation due to the toxicity of selenium which may be reached in sensitive individuals at a level as low as $600 \mu \mathrm{g} /$ day [278]. With this intake level in mind it is of interest that with the 
exception of high selenosis areas, none of the regions reported previously $[9,263]$ or in the current analysis (Table 1) reach a level of selenium intake that borders on the even more conservative upper limit of selenium intake of 400-450 $\mu \mathrm{g}$ /day recommended by the World Health Organisation [279]. As such controlled selenium supplementation within a population, in this case to pregnant women could be suggested as a possible measure to improve seleno-sufficiency particularly in populations known to have low selenium status. This may be an important consideration in countries around the world such as Australia and the United Kingdom [9, 280] where reductions in soil and plasma selenium concentrations have been noted over an extended period [9, 20, 280].

There are limited studies available that report selenium supplementation during pregnancy. However, all published studies available to date have reported reductions in the incidence of hypertensive complications of pregnancy in those patients with increased selenium intake [246, 281-283]. The largest of these studies was an analysis of the effect of multivitamin use in the Danish National Birth Cohort $(\mathrm{n}=28,601)$ where a multivitamin supplement containing $50 \mu \mathrm{g}$ selenium was most commonly taken [281]. Smaller studies that supplemented $100 \mu \mathrm{g}$ Se/day as part of a single micronutrient [246] or a more comprehensive antioxidant supplement [282] also demonstrated benefit, with no reported adverse consequences related to supplementation at either of these doses. It is also interesting to consider that the reported reduction in preeclampsia risk observed in these studies through selenium supplementation has not consistently been reported for supplementation with other exogenous antioxidant molecules such as vitamins C and E [284-286].

Preeclampsia is a disease unique to the human species and higher order primates. Limited experimental models of the disease exist, however the removal of selenium from the diet of rats has been found to induce a hypertensive/proteinuric state during pregnancy similar to that of preeclampsia [258]. The placentae from these pregnancies also showed decreased expression of endogenous antioxidants such as GPx and Thioredoxin reductase and a concomitant rise in biomarkers of oxidative stress. Conversely, in vitro and in vivo studies have demonstrated that selenium supplementation has a direct capacity to increase the activity of endogenous antioxidant enzymes [111] protecting placental tissue from oxidative damage. The importance of selenium to reproductive health may centre on the incorporation of selenium in the form of selenocysteine in the active site of endogenous antioxidant proteins such as Glutathione Peroxidase and Thioredoxin Reductase where it acts as a redox centre to combat oxidative damage from reactive oxygen species (ROS). However, other important selenoproteins may have a role to play in the etiology of preeclampsia including selenoproteins $\mathrm{P}, \mathrm{W}$ and S. Interestingly, a recent publication has shown a genetic association between Selenoprotein $\mathrm{S}$ and the development of preeclampsia and has 
postulated a role for this selenoprotein in the exacerbated inflammatory response associated development of the disease [287].

The current investigation has demonstrated globally, that a reduction in plasma selenium concentration is associated with an increased incidence of preeclampsia and that concentrations in excess of $95 \mu \mathrm{g} / \mathrm{L}$ may in fact be protective against the development of the disease. This study supports those previously reported that supplementing the diet of pregnant women with selenium [246, 281-283] may lower the incidence of preeclampsia and adds further weight to the current SPRINT (Selenium in Pregnancy Intervention) trial [288] running in the United Kingdom investigating the effect of $60 \mu \mathrm{g} /$ day selenium on the risk of preeclampsia (principal investigator MP Rayman [13]). Selenium supplementation either alone or in combination with a general multinutrient supplement may have a significant effect on not only the incidence of preeclampsia, but may also delay the onset and severity of the disease, ameliorating placental oxidative stress and buying valuable time for fetal development prior to delivery. Selenium supplementation may provide a readily applicable method of lessening the impact of this disease, and this may have considerable benefits to populations, especially those in developing countries 


\section{References}

1. Khalid SK, Daniel W, Lale S, Gülmezoglu AM, Paul FAVL. WHO analysis of causes of maternal death: a systematic review. The Lancet. 2006;367(9516):1066-74.

2. Hubel CA. Oxidative Stress in the Pathogenesis of Preeclampsia. Proceedings of the Society for Experimental Biology and Medicine. 1999;222(3):222-35.

3. Wang $\mathrm{Y}$, Walsh SW. Placental mitochondria as a source of oxidative stress in pre-eclampsia. Placenta. [doi: DOI: 10.1016/S0143-4004(98)90018-2]. 1998;19(8):581-6.

4. Jauniaux E, Poston L, Burton GJ. Placental-related diseases of pregnancy: involvement of oxidative stress and implications in human evolution. Human Reproduction Update. 2006 November/December 2006;12(6):747-55.

5. Brosens $I A$, Robertson WB, Dixon HG. The role of the spiral arteries in the pathogenesis of preeclampsia. Obstetrics and gynecology annual. 1972;1:177-91.

6. Redman CWG, Sargent IL. Placental Debris, Oxidative Stress and Pre-eclampsia. Placenta. [doi: DOI: 10.1053/plac.2000.0560]. 2000;21(7):597-602.

7. Perkins AV. Endogenous anti-oxidants in pregnancy and preeclampsia. Australian and New Zealand Journal of Obstetrics and Gynaecology. 2006;46(2):77-83.

8. Vanderlelie J, Venardos K, Clifton VL, Gude NM, Clarke FM, Perkins AV. Increased biological oxidation and reduced anti-oxidant enzyme activity in pre-eclamptic placentae. Placenta. [doi: DOI: 10.1016/j.placenta.2004.04.002]. 2005;26(1):53-8.

9. Rayman MP. The importance of selenium to human health. The Lancet. [doi: DOI: 10.1016/S01406736(00)02490-9]. 2000;356(9225):233-41.

10. Nève J. Selenium as a risk factor for cardiovascular diseases. European Journal of Cardiovascular Prevention \& Rehabilitation. 1996;3(1):42-7.

11. Ferencik $M$, Ebringer L. Modulatory effects of selenium and zinc on the immune system. Folia Microbiol (Praha). 2003;48(3):417-26.

12. Barrington JW, Lindsay $P$, James $D$, Smith $S$, Roberts $A$. Selenium deficiency and miscarriage: a possible link? Br J Obstet Gynaecol. 1996 Feb;103(2):130-2.

13. Rayman MP, Bode P, Redman CWG. Low selenium status is associated with the occurrence of the pregnancy disease preeclampsia in women from the United Kingdom. American Journal of Obstetrics and Gynecology. [doi: DOI: 10.1067/S0002-9378(03)00723-3]. 2003;189(5):1343-9.

14. Tapiero $\mathrm{H}$, Townsend DM, Tew KD. The antioxidant role of selenium and seleno-compounds. Biomedicine \& Pharmacotherapy. [doi: DOI: 10.1016/S0753-3322(03)00035-0]. 2003;57(3-4):134-44.

15. Bellinger FP, Raman AV, Reeves MA, Berry MJ. Regulation and function of selenoproteins in human disease. Biochem J. 2009 Aug 15;422(1):11-22.

16. Mistry HD, Wilson V, Ramsay MM, Symonds ME, Broughton Pipkin F. Reduced selenium concentrations and glutathione peroxidase activity in preeclamptic pregnancies. Hypertension. 2008 Nov;52(5):881-8.

17. Maleki A, Fard MK, Zadeh DH, Mamegani MA, Abasaizadeh S, Mazloomzadeh S. The Relationship between Plasma Level of Se and Preeclampsia. Hypertension in Pregnancy.0(0):1-8.

18. Reilly C. Selenium in food and health. 2nd ed. New York, N.Y.: Springer; 2006.

19. Broadley MR, White PJ, Bryson RJ, Meacham MC, Bowen HC, Johnson SE, et al. Biofortification of UK food crops with selenium. Proceedings of the Nutrition Society. 2006;65(02):169-81.

20. Lyons GH, Judson GJ, Ortiz-Monasterio I, Genc Y, Stangoulis JC, Graham RD. Selenium in Australia: selenium status and biofortification of wheat for better health. J Trace Elem Med Biol. 2005;19(1):75-82.

21. Thomson CD, Robinson MF. The changing selenium status of New Zealand residents. Eur J Clin Nutr. 1996 Feb;50(2):107-14.

22. Jackson MJ, Broome CS, MCArdle F. Marginal Dietary Selenium Intakes in the UK: Are There Functional Consequences? The Journal of Nutrition. 2003 May 1, 2003;133(5):1557S-9S.

23. Milne F, Redman C, Walker J, Baker P, Bradley J, Cooper C, et al. The pre-eclampsia community guideline (PRECOG): How to screen for and detect onset of pre-eclampsia in the community. British Medical Journal. 2005;330(7491):576-80. 
24. Thomson CD, Robinson MF, Butler JA, Whanger PD. Long-term supplementation with selenate and selenomethionine: Selenium and glutathione peroxidase (EC 1.11.1.9) in blood components of New Zealand women. British Journal of Nutrition. 1993;69(02):577-88.

25. Asfour I, El-Kholy NM, Ayoub AS, Ahmed MB, Bakarman A. Selenium and Glutathione Peroxidase Status in Adult Egyptian Patients with Acute Myeloid Leukemia. Haematol-Hematol J. 2009 Jun;94:546-.

26. Rasheed S, Abdelmonem A, Amin M. Adolescent pregnancy in Upper Egypt. International Journal of Gynecology \& Obstetrics. [doi: DOI: 10.1016/j.ijgo.2010.08.006]. 2011;112(1):21-4.

27. Maxia V, Meloni S, Rollier MA, Brandone A, Patwardhan VN, Waslien $\mathrm{Cl}$, et al. Selenium and chromium assay in Egyptian foods and in blood of Egyptian children by activation analysis. Journal Name: pp 527-550 of Nuclear activation techniques in the life sciences, 1972 Vienna International Atomic Energy Agency, 1972; Other Information: From Symposium on nuclear activation techniques in life sciences, Bled, Yugoslavia, 10 Apr 1972, 14 Apr 1972 See CONF-720425-- Orig Receipt Date: 30-JUN-73. 1973:Medium: X.

28. Ojo JO, Oluwole AF, Durosinmi MA, Ogunsola OJ, Akanle OA, Spyrou NM. Baseline levels of elemental concentrations in whole blood, plasma, and erythrocytes of Nigerian subjects. Biol Trace Elem Res. 1994 Fall;43-45:461-9.

29. Okafor UV, Okezie O. Maternal and fetal outcome of anaesthesia for caesarean delivery in preeclampsia/eclampsia in Enugu, Nigeria: a retrospective observational study. Int J Obstet Anesth. 2005 Apr;14(2):108-13.

30. Cenac A, Simonoff $M$, Djibo A. Nutritional status and plasma trace elements in peripartum cardiomyopathy. A comparative study in Niger. J Cardiovasc Risk. 1996 Dec;3(6):483-7.

31. Gopalan C. Effect of nutrition on pregnancy and lactation. Bull World Health Organ. 1962;26:203-

11.

32. Dawson B. [The prevention of eclampsia.]. J Obstet Gynaecol Br Emp. 1953 Feb;60(1):80-4.

33. Robinson MF, Godfrey PJ, Thomson CD, Rea HM, van Rij AM. Blood selenium and glutathione peroxidase activity in normal subjects and in surgical patients with and without cancer in New Zealand. Am J Clin Nutr. 1979 Jul;32(7):1477-85.

34. Stewart RD, Griffiths NM, Thomson CD, Robinson MF. Quantitative selenium metabolism in normal New Zealand women. Br J Nutr. 1978 Jul;40(1):45-54.

35. Rea HM, Thomson CD, Campbell DR, Robinson MF. Relation between erythrocyte selenium concentrations and glutathione peroxidase (EC 1.11.1.9) activities of New Zealand residents and visitors to New Zealand. Br J Nutr. 1979 Sep;42(2):201-8.

36. van Rij AM, McKenzie JM, Thomson CD, Robinson MF. Selenium supplementation in total parenteral nutrition. JPEN J Parenter Enteral Nutr. 1981 Mar-Apr;5(2):120-4.

37. Thomson CD, Robinson MF, Campbell DR, Rea HM. Effect of prolonged supplementation with daily supplements of selenomethionine and sodium selenite on glutathione peroxidase activity in blood of New Zealand residents. Am J Clin Nutr. 1982 Jul;36(1):24-31.

38. Thomson CD, Ong LK, Robinson MF. Effects of supplementation with high-selenium wheat bread on selenium, glutathione peroxidase and related enzymes in blood components of New Zealand residents. Am J Clin Nutr. 1985 May;41(5):1015-22.

39. Thomson CD, Robinson MF. Urinary and fecal excretions and absorption of a large supplement of selenium: superiority of selenate over selenite. Am J Clin Nutr. 1986 Nov;44(5):659-63.

40. Thomson CD, Steven SM, Vanrij AM, Wade CR, Robinson MF. Selenium and Vitamin-E Supplementation - Activities of Glutathione-Peroxidase in Human-Tissues. American Journal of Clinical Nutrition. 1988 Aug;48(2):316-23.

41. Vannoort RW, New Zealand. Ministry of Health., New Zealand. Public Health Commission. 1990/1991 New Zealand total diet survey : prepared as part of a Ministry of Health/Public Health Commission contract for scientific services. Wellington: ESR Health : Wellington Science Centre; 1995.

42. Bratakos MS, Kanaki HC, Vasiliou-Waite A, loannou PV. The nutritional selenium status of healthy Greeks. Sci Total Environ. 1990 Feb;91:161-76.

43. Thorling EB, Overvad K, Geboers J. Selenium status in Europe--human data. A multicenter study. Ann Clin Res. 1986;18(1):3-7. 
44. Allen NE, Appleby PN, Roddam AW, Tjønneland A, Johnsen NF, Overvad K, et al. Plasma selenium concentration and prostate cancer risk: results from the European Prospective Investigation into Cancer and Nutrition (EPIC). The American Journal of Clinical Nutrition. 2008 December 1, 2008;88(6):1567-75.

45. Bratakos MS, loannou PV. Selenium in human milk and dietary selenium intake by Greeks. Sci Total Environ. 1991 Jun;105:101-7.

46. Anastasiadis P, Tsikouras P, Galazios G, Liberis V, Grapsas X, Koutlaki N, et al. Hypertensive disorders in pregnancy: risk factors and epidemiologic analysis. Clin Exp Obstet Gynecol. 2007;34(3):154-8.

47. Tzoumaka-Bakoula C, Lekea-Karanika V, Golding J, Thomas P. Hypertensive disorders of pregnancy in Greece. Eur J Obstet Gynecol Reprod Biol. 1989 May;31(2):127-31.

48. Klapec T, Mandic ML, Grgic J, Primorac L, Ikic M, Lovric T, et al. Daily dietary intake of selenium in eastern Croatia. Sci Total Environ. 1998 Jun 30;217(1-2):127-36.

49. Pavlinac I, Marin A, Valic M, Marusic J, Roje D, Pecotic R, et al. Influence of the wars in Croatia and Bosnia and Herzegovina on the incidence and outcome of singleton premature births in the Split University Hospital. Cent Eur J Med. 2008 Jun;3(2):187-93.

50. Buljevac M, Vucelic B, Romic Z, Banic M. Selenium in serum of the patients with increased risk of developing colorectal carcinoma and patients with colorectal carcinoma. Collegium Antropol. 1995 Dec;19(2):485-91.

51. Aro A, Alfthan G, Varo P. Effects of supplementation of fertilizers on human selenium status in Finland. Analyst. 1995 Mar;120(3):841-3.

52. Kumpulainen J, Vuori E, Kuitunen P, Makinen S, Kara R. Longitudinal study on the dietary selenium intake of exclusively breast-fed infants and their mothers in Finland. Int J Vitam Nutr Res. 1983;53(4):420-6.

53. Kumpulainen JT. Selenium in Foods and Diets of Selected Countries. J Trace Elem Elect H. 1993 Jun;7(2):107-8.

54. Varo P, Alfthan G, Ekholm P, Aro A, Koivistoinen P. Selenium Intake and Serum Selenium in Finland Effects of Soil Fertilization with Selenium. American Journal of Clinical Nutrition. 1988 Aug;48(2):324-9.

55. Kajantie E, Eriksson JG, Osmond C, Thornburg K, Barker DJP. Pre-Eclampsia Is Associated With Increased Risk of Stroke in the Adult Offspring The Helsinki Birth Cohort Study. Stroke. 2009 Apr;40(4):1176-80.

56. Nafstad P, Samuelsen SO, Irgens LM, Bjerkedal T. Pregnancy complications and the risk of asthma among Norwegians born between 1967 and 1993. European Journal of Epidemiology. 2003;18(8):755-61.

57. Alfthan G. Longitudinal-Study on the Selenium Status of Healthy-Adults in Finland during 1975 1984. Nutr Res. 1988 May;8(5):467-76.

58. Dahlstrom BL, Engh ME, Bukholm G, Oian P. Changes in the prevalence of pre-eclampsia in Akershus County and the rest of Norway during the past 35 years. Acta Obstet Gynecol Scand. 2006;85(8):916-21.

59. Westermarck T. Selenium content of tissues in Finnish infants and adults with various diseases, and studies on the effects of selenium supplementation in neuronal ceroid lipofuscinosis patients. Acta Pharmacol Toxicol (Copenh). 1977 Aug;41(2):121-8.

60. Arvilommi H, Poikonen K, Jokinen I, Muukkonen O, Rasanen L, Foreman J, et al. Selenium and immune functions in humans. Infect Immun. $1983 \mathrm{Jul} ; 41(1): 185-9$.

61. Levander OA, Alfthan G, Arvilommi H, Gref CG, Huttunen JK, Kataja M, et al. Bioavailability of selenium to Finnish men as assessed by platelet glutathione peroxidase activity and other blood parameters. Am J Clin Nutr. 1983 Jun;37(6):887-97.

62. Salonen JT, Alfthan G, Huttunen JK, Pikkarainen J, Puska P. Association between cardiovascular death and myocardial infarction and serum selenium in a matched-pair longitudinal study. Lancet. 1982 Jul 24;2(8291):175-9.

63. Valimaki MJ, Harju KJ, Ylikahri RH. Decreased serum selenium in alcoholics--a consequence of liver dysfunction. Clin Chim Acta. 1983 Jun 15;130(3):291-6.

64. Alfthan G, Penttila A. Effect of fat on human liver selenium concentration. Biol Trace Elem Res. 1988 Dec;18:137-43.

65. Marklund SL, Repo H, Koskimies S. Superoxide dismutase isoenzymes, glutathione peroxidase and selenium in blood from HLA-B27-positive and -negative subjects. Acta Pathol Microbiol Immunol Scand C. 1987 Jun;95(3):107-11. 
66. Virtamo J, Valkeila E, Alfthan G, Punsar S, Huttunen JK, Karvonen MJ. Serum selenium and risk of cancer. A prospective follow-up of nine years. Cancer. $1987 \mathrm{Jul}$ 15;60(2):145-8.

67. Scieszka M, Danch A, Machalski M, Drozdz M. Plasma selenium concentration in patients with stomach and colon cancer in the Upper Silesia. Neoplasma. 1997;44(6):395-7.

68. Pilarczyk B, Tomza-Marciniak A, Mituniewicz-Malek A, Wieczorek-Dabrowska M, Pilarczyk R, Wojcik $\mathrm{J}$, et al. Selenium content in selected products of animal origin and estimation of the degree of cover daily Se requirement in Poland. Int J Food Sci Tech. 2010 Jan;45(1):186-91.

69. Zachara B, Gromadzinska J, Wasowicz W. [Selenium concentration and glutathione peroxidase activity in the blood, erythrocytes and plasma]. Pol Tyg Lek. 1983 Jul 11-18;38(28-29):897-900.

70. Zachara BA, Wasowicz W, Sklodowska M, Gromadzinska J. Selenium Status, Lipid Peroxides Concentration, and Glutathione-Peroxidase Activity in the Blood of Power-Station and Rubber FactoryWorkers. Archives of Environmental Health. 1987 Jul-Aug;42(4):223-9.

71. Wasowicz W, Zachara BA. Selenium Concentrations in the Blood and Urine of a Healthy Polish Subpopulation. J Clin Chem Clin Bio. 1987 Jul;25(7):409-12.

72. Czuczejko J, Halota W, Zachara BA, Staubach-Topczewska E. [Plasma selenium concentration, glutathione peroxidase and glutathione S-transferase activities in patients with chronic liver diseases]. Pol Merkur Lekarski. 2002 Oct;13(76):312-5.

73. Hincz P, Borowski D, Krekora M, Podciechowski L, Horzelski W, Wilczynski J. Maternal obesity as a perinatal risk factor. Ginekol Pol. 2009 May;80(5):334-7.

74. Maihara VA, Gonzaga IB, Silva VL, Favaro DIT, Vasconcellos MBA, Cozzolino SMF. Daily dietary selenium intake of selected Brazilian population groups. J Radioanal Nucl Ch. 2004;259(3):465-8.

75. Gaio DS, Schmidt MI, Duncan BB, Nucci LB, Matos MC, Branchtein L. Hypertensive disorders in pregnancy: frequency and associated factors in a cohort of Brazilian women. Hypertens Pregnancy. 2001;20(3):269-81.

76. Rivera MT, De Souza AP, Moreno AHM, Xavier SS, Gomes JAS, Rocha MOC, et al. Progressive Chagas' cardiomyopathy is associated with low selenium levels. Am J Trop Med Hyg. 2002 Jun;66(6):706-12.

77. Allegrini M, Lanzola, E., Gallorini, M. Dietary Selenium intake in a coronary heart disease study in Northern Italy. Nutr Res. 1985;Supplement 1:398-402.

78. Vesce F, Farina A, Giorgetti M, Jorizzo G, Bianciotto A, Calabrese O, et al. Increased incidence of preeclampsia in pregnancies complicated by fetal malformation. Gynecol Obstet Inves. 1997;44(2):107-11.

79. Ravaglia G, Forti P, Maioli F, Bastagli L, Facchini A, Mariani E, et al. Effect of micronutrient status on natural killer cell immune function in healthy free-living subjects aged $>=90 \mathrm{y}$. American Journal of Clinical Nutrition. 2000 Feb;71(2):590-8.

80. Olivieri O, Girelli D, Azzini M, Stanzial AM, Russo C, Ferroni M, et al. Low Selenium Status in the Elderly Influences Thyroid-Hormones. Clin Sci. 1995 Dec;89(6):637-42.

81. Olivieri O, Girelli D, Stanzial AM, Rossi L, Bassi A, Corrocher R. Selenium, zinc, and thyroid hormones in healthy subjects - Low T-3/T-4 ratio in the elderly is related to impaired selenium status. Biological Trace Element Research. 1996 Jan;51(1):31-41.

82. Olivieri O, Stanzial AM, Girelli D, Trevisan MT, Guarini P, Terzi M, et al. Selenium Status, Fatty-Acids, Vitamin-a and Vitamin-E, and Aging - the Nove Study. American Journal of Clinical Nutrition. 1994 Oct;60(4):510-7.

83. Bonomini M, Forster S, Derisio F, Rychly J, Nebe B, Manfrini V, et al. Effects of Selenium Supplementation on Immune Parameters in Chronic Uremic Patients on Hemodialysis. Nephrol Dial Transpl. 1995;10(9):1654-61.

84. Bellisola G, Perona G, Galassini S, Moschini G, Guidi GC. Plasma selenium and glutathione peroxidase activities in individuals living in the Veneto region of Italy. J Trace Elem Electrolytes Health Dis. $1993 \mathrm{Dec} ; 7(4): 242-4$.

85. Mahapatra S, Tripathi RM, Raghunath R, Sadasivan S. Daily intake of Se by adult population of Mumbai, India. Science of the Total Environment. 2001 Sep 28;277(1-3):217-23.

86. Gambhir JK, Lali P. Blood selenium levels in healthy Indian subjects and patients with rheumatoid arthritis. Clin Biochem. 1999 Nov;32(8):665-6.

87. Yadav S, Day JP, Mohan V, Snehalatha C, Braganza JM. Selenium and diabetes in the tropics. Pancreas. 1991 Sep;6(5):528-33. 
88. Srikumar TS, Johansson GK, Ockerman PA, Gustafsson JA, Akesson B. Trace element status in healthy subjects switching from a mixed to a lactovegetarian diet for 12 mo. Am J Clin Nutr. 1992 Apr;55(4):885-90.

89. Mahalingam TR, Vijayalakshmi S, Prabhu RK, Thiruvengadasami A, Wilber A, Mathews CK, et al. Studies on some trace and minor elements in blood. A survey of the Kalpakkam (India) population. Part III: Studies on dietary intake and its correlation to blood levels. Biol Trace Elem Res. 1997 Jun;57(3):223-38.

90. Subramaniam V. Seasonal variation in the incidence of preeclampsia and eclampsia in tropical climatic conditions. BMC Womens Health. 2007;7:18.

91. Bro S, Sandstrom B, Heydorn K. Intake of Essential and Toxic Trace-Elements in a Random Sample of Danish Men as Determined by the Duplicate Portion Sampling Technique. J Trace Elem Elect H. 1990 Sep;4(3):147-55.

92. Ehrenstein V, Rothman KJ, Pedersen L, Hatch EE, Sørensen HT. Pregnancy-associated Hypertensive Disorders and Adult Cognitive Function Among Danish Conscripts. American Journal of Epidemiology. 2009 October 15, 2009;170(8):1025-31.

93. Thorling EB, Overvad K, Heerfordt A, Foldspang A. Serum Selenium in Danish Blood-Bank Donors. Biological Trace Element Research. 1985;8(1):65-73.

94. Tarp U, Thorling EB, Hansen JC. Longitudinal study of changes in blood selenium among danish blood bank donors (1974-1988). Nutr Res. [doi: DOI: 10.1016/S0271-5317(05)80339-2]. 1990;10(10):11716.

95. Alexander JM, H.M. In: Oskarsson A, editor. Risk evaluation of essential trace elements - essential versus toxic

levels of intake

Copenhagen: Nordic Council of Ministers; 1995. p. 15-65.

96. Murphy J, Cashman K. Selenium status of Irish adults: evidence of insufficiency. Irish Journal of Medical Science. 2002;171(2):81-4.

97. Murphy J, Hannon EM, Kiely M, Flynn A, Cashman KD. Selenium intakes in 18-64-y-old Irish adults. European Journal of Clinical Nutrition. 2002 May;56(5):402-8.

98. Higgins JR, Walshe JJ, Conroy RM, Darling MRN. The relation between maternal work, ambulatory blood pressure, and pregnancy hypertension. Journal of Epidemiology and Community Health. 2002 May 1, 2002;56(5):389-93.

99. Higgins JR, Walshe JJ, Halligan A, O'Brien E, Conroy R, Darling MRN. Can 24-hour ambulatory blood pressure measurement predict the development of hypertension in primigravidae? BJOG: An International Journal of Obstetrics \& Gynaecology. 1997;104(3):356-62.

100. Darling G, Mathias P, O'Regan M, Naughten E. Serum selenium levels in individuals on PKU diets. J Inherit Metab Dis. 1992;15(5):769-73.

101. Alfthan G, Bogye G, Aro A, Feher J. The human selenium status in Hungary. J Trace Elem Electrolytes Health Dis. 1992 Dec;6(4):233-8.

102. Cser A, Sziklai-Laszlo I, Menzel H, Lombeck I. Selenium status and lipoproteins in healthy and diabetic children. J Trace Elem Electrolytes Health Dis. 1993 Dec;7(4):205-10.

103. Cser MA, Sziklai-Laszlo I, Menzel H, Lombeck I. Selenium and glutathione peroxidase activity in Hungarian children. J Trace Elem Med Biol. 1996 Sep;10(3):167-73.

104. Molnar J, Garamvolgyi Z, Herold M, Adanyi N, Somogyi A, Rigo J. Serum Selenium Concentrations Correlate Significantly with Inflammatory Biomarker High-sensitive CRP Levels in Hungarian Gestational Diabetic and Healthy Pregnant Women at Mid-pregnancy. Biological Trace Element Research. 2008;121(1):16-22.

105. Banhidy F, Acs N, Puho EH, Czeizel AE. Iron deficiency anemia: Pregnancy outcomes with or without iron supplementation. Nutrition. 2010 Apr 7.

106. Rafraf M, Mahdavi R, Rashidi MR. Serum selenium levels in healthy women in Tabriz, Iran. Food Nutr Bull. 2008 Jun;29(2):83-6.

107. Kazemi AFN, Sehhatie, F., Sattarzad, N., Mameghani, M.E The Predictive Value of Urinary Calcium to Creatinine Ratio, Roll-Over Test and BMI in Early Diagnosis of Pre-Eclampsia. Research Journal of Biological Sciences. 2010;5(2):183-6. 
108. Sadjadi A, Marjani, H., Semnani, S., Nasseri-Moghaddam, S. Esophageal Cancer in Iran: A Review. Middle East Journal of Cancer 2010;1(1):5-14.

109. Poon LC, Kametas NA, Chelemen T, Leal A, Nicolaides KH. Maternal risk factors for hypertensive disorders in pregnancy: a multivariate approach. J Hum Hypertens. 2010 Feb;24(2):104-10.

110. Barclay MNI, MacPherson A, Dixon J. Selenium Content of a Range of UK Foods. Journal of Food Composition and Analysis. [doi: DOI: 10.1006/jfca.1995.1025]. 1995;8(4):307-18.

111. Brown KM, Pickard K, Nicol F, Beckett GJ, Duthie GG, Arthur JR. Effects of organic and inorganic selenium supplementation on selenoenzyme activity in blood lymphoctyes, granulocytes, platelets and erythrocytes. Clin Sci. 2000 May , 2000;98(5):593-9.

112. Food Surveillance Information Sheet, No 126, MAFF UK Dietary Intake of Selenium. In: (MAFF) UMoAFaF, editor. London: Joint Food Safety Standards Group; 1997.

113. Díaz-Alarcón JP, Navarro-Alarcón M, López-García de la Serrana H, López-Martínez MC. Determination of selenium in cereals, legumes and dry fruits from southeastern Spain for calculation of daily dietary intake. Science of The Total Environment. [doi: DOI: 10.1016/0048-9697(96)05079-6]. 1996;184(3):183-9.

114. Suy A CO, Martinez E, Lonca M, de Lazzari E, Pisa S, Larrouse M, Milinkovic A, Hernandez S, Blanco JL, Mallolas J, Garcia F, Miro JM, Cararach V, Vanrell JA, Gatell JM. Increased risk of pre-pclampsia and fetal death in HIV-infected pregnant women receiving highly active antiretroviral therapy. International Conference on AIDS Jul 11-16; 15; Bangkok, Thailand2004. p. .

115. Ros HS, Cnattingius S, Lipworth L. Comparison of risk factors for preeclampsia and gestational hypertension in a population-based cohort study. Am J Epidemiol. 1998 Jun 1;147(11):1062-70.

116. Michaelsson G, Berne B, Carlmark B, Strand A. Selenium in whole blood and plasma is decreased in patients with moderate and severe psoriasis. Acta Derm Venereol. 1989;69(1):29-34.

117. Thorngren $\mathrm{M}$, Akesson B. Effect of dietary fish on plasma selenium and its relation to haemostatic changes in healthy adults. Int J Vitam Nutr Res. 1987;57(4):429-35.

118. Gebre-Medhin M, Gustavson KH, Gamstorp I, Plantin LO. Selenium supplementation in X-linked muscular dystrophy. Effects on erythrocyte and serum selenium and on erythrocyte glutathione peroxidase activity. Acta Paediatr Scand. 1985 Nov;74(6):886-90.

119. Anneren G, Gebre-Medhin M, Gustavson KH, Plantin LO. Selenium in plasma and erythrocytes in patients with Down's syndrome and healthy controls. Variation in relation to age, sex and glutathione peroxidase activity in erythrocytes. Acta Paediatr Scand. 1985 Jul;74(4):508-14.

120. Jorhem L, Becker W, Slorach S. Intake of 17 Elements by Swedish Women, Determined by a 24-h Duplicate Portion Study. Journal of Food Composition and Analysis. [doi: DOI: 10.1006/jfca.1998.0562]. 1998;11(1):32-46.

121. Oster O, Prellwitz W. The daily dietary selenium intake of West German adults. Biol Trace Elem Res. 1989 Apr-May;20(1-2):1-14.

122. Oster O, Schmiedel G, Prellwitz W. The organ distribution of selenium in German adults. Biol Trace Elem Res. 1988 Jan-Apr;15:23-45.

123. Hammoud AO, Bujold E, Sorokin Y, Schild C, Krapp M, Baumann P. Smoking in pregnancy revisited: Findings from a large population-based study. American Journal of Obstetrics and Gynecology. 2005 Jun;192(6):1856-62.

124. Reime B, Ratner PA, Tomaselli-Reime SN, Kelly A, Schuecking BA, Wenzlaff P. The role of mediating factors in the association between social deprivation and low birth weight in Germany. Soc Sci Med. 2006 Apr;62(7):1731-44.

125. Murphy C, Golden, B., Ramdath, D., Golden, M. Selenium status during recovery from malnutrition: Effect of selenium supplementation. In: Hurley LS, Keen, C.L., Lonnerdal, B., Rucker, R.B., editor. Trace Element Metabolism in Man and Animals

New York: Plenum Press; 1988. p. 11-4.

126. Golding J, on behalf of The Jamaica Low Dose Aspirin Study G. A randomised trial of low dose aspirin for primiparae in pregnancy. BJOG: An International Journal of Obstetrics \& Gynaecology. 1998;105(3):293-9.

127. Robberecht HJ, Hendrix P, Vancauwenbergh R, Deelstra HA. Actual Daily Dietary-Intake of Selenium in Belgium, Using Duplicate Portion Sampling. Z Lebensm Unters For. 1994 Oct;199(4):251-4. 
128. Robberecht HJ, Hendrix P, Van Cauwenbergh R, Deelstra HA. Actual daily dietary intake of selenium in Belgium, using duplicate portion sampling. Z Lebensm Unters Forsch. 1994 Oct;199(4):251-4.

129. Kyrou D, Kolibianakis EM, Devroey P, Fatemi HM. Is the use of donor sperm associated with a higher incidence of preeclampsia in women who achieve pregnancy after intrauterine insemination? Fertil Steril. 2010 Mar 1;93(4):1124-7.

130. Brosens IA, De Sutter P, Hamerlynck T, Imeraj L, Yao Z, Cloke B, et al. Endometriosis is associated with a decreased risk of pre-eclampsia. Human Reproduction. 2007 Jun;22(6):1725-9.

131. Van Cauwenbergh R, Robberecht $H$, Van Vlaslaer V, De Smet A, Emonds MP, Hermans N. Plasma selenium levels in healthy blood bank donors in the central-eastern part of Belgium. J Trace Elem Med Biol. 2007;21(4):225-33.

132. Scott R, MacPherson A, Yates RW, Hussain B, Dixon J. The effect of oral selenium supplementation on human sperm motility. Br J Urol. 1998 Jul;82(1):76-80.

133. Barclay MNI, Macpherson A. Selenium Content of Wheat for Bread Making in Scotland and the Relationship between Glutathione-Peroxidase (Ec 1.11.1.9) Levels in Whole-Blood and Bread Consumption. British Journal of Nutrition. 1992 Jul;68(1):261-70.

134. Shortt CT, Duthie GG, Robertson JD, Morrice PC, Nicol F, Arthur JR. Selenium status of a group of Scottish adults. European Journal of Clinical Nutrition. 1997 Jun;51(6):400-4.

135. Lawlor DA, Morton SMB, Nitsch D, Leon DA. Association between childhood and adulthood socioeconomic position and pregnancy induced hypertension: results from the Aberdeen children of the 1950s cohort study. Journal of Epidemiology and Community Health. 2005 Jan;59(1):49-55.

136. Pell JP, Smith GC, Walsh D. Pregnancy complications and subsequent maternal cerebrovascular events: a retrospective cohort study of 119,668 births. Am J Epidemiol. 2004 Feb 15;159(4):336-42.

137. Wiles NJ, Peters TJ, Leon DA, Lewis G. Birth weight and psychological distress at age 45-51 years: results from the Aberdeen Children of the 1950s cohort study. Br J Psychiatry. 2005 Jul;187:21-8.

138. Nohr EA, Bech BH, Davies MJ, Frydenberg M, Henriksen TB, Olsen J. Prepregnancy Obesity and Fetal Death: A Study Within the Danish National Birth Cohort. Obstetrical \& Gynecological Survey. 2006;61(1):78.

139. Rode L, Nilas L, Wøjdemann K, Tabor A. Obesity-Related Complications in Danish Single Cephalic Term Pregnancies. Obstetrics \& Gynecology. 2005;105(3):537-42 10.1097/01.AOG.0000152304.39492.1c.

140. Flynn A, Hirvonen T, Mensink GB, Ocke MC, Serra-Majem L, Stos K, et al. Intake of selected nutrients from foods, from fortification and from supplements in various European countries. Food Nutr Res. 2009;53.

141. Tarp U, Overvad K, Hansen JC, Thorling EB. Selenium and rheumatoid arthritis. Scand J Rheumatol. 1986;15(1):96.

142. Bro S, Berendtsen H, Norgaard J, Host A, Jorgensen PJ. Serum selenium concentration in maternal and umbilical cord blood. Relation to course and outcome of pregnancy. J Trace Elem Electrolytes Health Dis. 1988 Sep;2(3):165-9.

143. Grandjean P, Weihe P, Jorgensen PJ, Clarkson T, Cernichiari E, Videro T. Impact of maternal seafood diet on fetal exposure to mercury, selenium, and lead. Arch Environ Health. 1992 May-Jun;47(3):185-95.

144. Suadicani P, Hein HO, Gyntelberg F. Serum selenium concentration and risk of ischaemic heart disease in a prospective cohort study of 3000 males. Atherosclerosis. 1992 Sep;96(1):33-42.

145. Basso O, Weinberg CR, Baird DD, Wilcox AJ, Olsen J. Subfecundity as a Correlate of Preeclampsia: A Study within the Danish National Birth Cohort. American Journal of Epidemiology. 2003 February 1, 2003;157(3):195-202.

146. Xia Y, Zhao X, Zhu L, Whanger PD. Distribution of selenium in erythrocytes, plasma, and urine of Chinese men of different selenium status. The Journal of Nutritional Biochemistry. [doi: DOI: 10.1016/09552863(92)90042-H]. 1992;3(5):211-6.

147. Baulon E, Fraser W, Piedboeuf B, Buekens P, Xiong X. Pregnancy-induced hypertension and infant growth at 28 and 42 days postpartum. BMC Pregnancy and Childbirth. 2005;5(1):10.

148. Zhang ZW, Shimbo S, Qu JB, Watanabe T, Nakatsuka H, Matsuda-Inoguchi N, et al. Dietary selenium intake of Chinese adult women in the 1990s. Biol Trace Elem Res. 2001 May;80(2):125-38.

149. Mcorist GD, Fardy JJ. Selenium Status in the Blood of Australians Using Neutron-Activation Analysis. J Radioan Nucl Ch Ar. 1989 Nov;134(1):65-72. 
150. Dhindsa HS, Bermingham MA, Mierzwa J, Sullivan D. Plasma selenium concentrations in a Sikh population in Sydney, Australia. Analyst. 1998 May;123(5):885-7.

151. Hadfield RM, Lain SJ, Raynes-Greenow CH, Morris JM, Roberts CL. Is there an association between endometriosis and the risk of pre-eclampsia? A population based study. Human Reproduction. 2009 September 1, 2009;24(9):2348-52.

152. Ostlund I, Haglund B, Hanson U. Gestational diabetes and preeclampsia. Eur J Obstet Gynecol Reprod Biol. 2004 Mar 15;113(1):12-6.

153. Wikström A-K, Stephansson O, Cnattingius S. Previous preeclampsia and risks of adverse outcomes in subsequent nonpreeclamptic pregnancies. American Journal of Obstetrics and Gynecology. [doi: DOI: 10.1016/j.ajog.2010.09.003].In Press, Corrected Proof.

154. Zhang. X. et al. Northern Territory Midwives' Collection. Mothers and Babies 2003-2005. . Darwin: Department of Health and Families; 2009.

155. Hardell L, Degerman A, Tomic R, Marklund SL, Bergfors M. Levels of selenium in plasma and glutathione peroxidase in erythrocytes in patients with prostate cancer or benign hyperplasia. Eur J Cancer Prev. 1995 Feb;4(1):91-5.

156. Hardell L, Danell M, Angqvist CA, Marklund SL, Fredriksson M, Zakari AL, et al. Levels of selenium in plasma and glutathione peroxidase in erythrocytes and the risk of breast cancer. A case-control study. Biol Trace Elem Res. 1993 Feb;36(2):99-108.

157. Valentine JL, Cebrian ME, Garcia-vargas GG, Faraji B, Kuo J, Gibb HJ, et al. Daily selenium intake estimates for residents of arsenic-endemic areas. Environ Res. 1994 Jan;64(1):1-9.

158. Sanchez-Ocampo A, Torres-Perez J, Jimenez-Reyes M. Selenium levels in the serum of workers at a rubber tire repair shop. Am Ind Hyg Assoc J. 1996 Jan;57(1):72-5.

159. Lumbiganon P, Gulmezoglu AM, Piaggio G, Langer A, Grimshaw J. Magnesium sulfate is not used for pre-eclampsia and eclampsia in Mexico and Thailand as much as it should be. B World Health Organ. 2007 Oct;85(10):763-7.

160. Engel SM, Janevic TM, Stein CR, Savitz DA. Maternal smoking, preeclampsia, and infant health outcomes in New York City, 1995-2003. Am J Epidemiol. 2009 Jan 1;169(1):33-40.

161. Weissgerber TL, Wolfe LA, Davies GA. The role of regular physical activity in preeclampsia prevention. Med Sci Sports Exerc. 2004 Dec;36(12):2024-31.

162. Weiss JL, Malone, F.D., Emig. D., Ball, R.H., Nyberg, D.A., Comstock, C.H., Saade, G., Eddleman, K., Carter, S.M., Craigo, S.D., Carr, S.R., D'Alton, M.E. . Obesity, obstetric complications and cesarean delivery rate-a population-based screening study. American Journal of Obstetrics and Gynecology. 2004;190(4):1091-7.

163. Pleban PA, Munyani A, Beachum J. Determination of selenium concentration and glutathione peroxidase activity in plasma and erythrocytes. Clin Chem. 1982 Feb;28(2):311-6.

164. Swanson CA, Longnecker MP, Veillon C, Howe M, Levander OA, Taylor PR, et al. Selenium intake, age, gender, and smoking in relation to indices of selenium status of adults residing in a seleniferous area. Am J Clin Nutr. 1990 Nov;52(5):858-62.

165. Dworkin BM, Rosenthal WS. Selenium and the alcoholic. Lancet. 1984 May 5;1(8384):1015.

166. Pothier L, Lane WW, Bhargava A, Michielson C, Douglass HO. Plasma selenium levels in patients with advanced upper gastrointestinal cancer. Cancer. 1987;60(9):2251-60.

167. Levander OA, Moser PB, Morris VC. Dietary selenium intake and selenium concentrations of plasma, erythrocytes, and breast milk in pregnant and postpartum lactating and nonlactating women. Am J Clin Nutr. 1987 Oct;46(4):694-8.

168. Bianco AT, Smilen SW, Davis Y, Lopez S, Lapinski R, Lockwood CJ. Pregnancy outcome and weight gain recommendations for the morbidly obese woman. Obstet Gynecol. 1998 Jan;91(1):97-102.

169. Bodnar LM, Ness RB, Markovic N, Roberts JM. The Risk of Preeclampsia Rises with Increasing Prepregnancy Body Mass Index. Annals of Epidemiology. [doi: DOI: 10.1016/j.annepidem.2004.12.008]. 2005;15(7):475-82.

170. Vollebregt KC, Wolf H, Boer K, van der Wal MF, Vrijkotte TGM, Bonsel GJ. Does physical activity in leisure time early in pregnancy reduce the incidence of preeclampsia or gestational hypertension? Acta Obstet Gyn Scan. 2010 Feb;89(2):261-7. 
171. Knuist M, Bonsel GJ, Zondervan HA, Treffers PE. Risk factors for preeclampsia in nulliparous women in distinct ethnic groups: A prospective cohort study. Obstetrics and Gynecology. 1998 Aug;92(2):174-8.

172. Vandertorre HW, Vandokkum W, Schaafsma G, Wedel M, Ockhuizen T. Effect of Various Levels of Selenium in Wheat and Meat on Blood Se Status Indexes and on Se Balance in Dutch Men. British Journal of Nutrition. 1991 Jan;65(1):69-80.

173. Vandokkum W, Devos RH, Muys T, Wesstra JA. Minerals and Trace-Elements in Total Diets in the Netherlands. British Journal of Nutrition. 1989 Jan;61(1):7-15.

174. Viegas-Crespo AM, Neve J, Monteiro ML, Amorim MF, Paulo OS, Halpern MJ. Selenium and lipid parameters in plasma of Portuguese subjects. J Trace Elem Electrolytes Health Dis. 1994 Jun;8(2):119-22.

175. Povoa AM, Costa F, Rodrigues T, Patricio B, Cardoso F. Prevalence of hypertension during pregnancy in Portugal. Hypertens Pregnancy. 2008;27(3):279-84.

176. Al-Ahmary KM. Selenium content in selected foods from the Saudi Arabia market and estimation of the daily intake. Arabian Journal of Chemistry. [doi: DOI: 10.1016/j.arabjc.2009.10.004]. 2009;2(2):95-9.

177. Raines DA, Kinsara AJ, Eid Fawzy M, Vasudevan S, Mohamed GE, Legayada ES, et al. Plasma and urinary selenium in Saudi Arabian patients with dilated cardiomyopathy. Biol Trace Elem Res. 1999 Jul;69(1):59-68.

178. Lawoyin TO, Ani F. Epidemiologic aspects of pre-eclampsia in Saudi Arabia. East Afr Med J. 1996 Jun;73(6):404-6.

179. Anttolainen M, Valsta LM, Alfthan G, Kleemola P, Salminen I, Tamminen M. Effect of extreme fish consumption on dietary and plasma antioxidant levels and fatty acid composition. Eur J Clin Nutr. 1996 Nov;50(11):741-6.

180. Jarvelin MR, Elliott P, Kleinschmidt I, Martuzzi M, Grundy C, Hartikainen AL, et al. Ecological and individual predictors of birthweight in a northern Finland birth cohort 1986. Paediatr Perinat Ep. 1997 Jul;11(3):298-312.

181. Salonen JT, Salonen R, Seppanen K, Kantola M, Parviainen M, Alfthan G, et al. Relationship of Serum Selenium and Antioxidants to Plasma-Lipoproteins, Platelet Aggregability and Prevalent Ischemic HeartDisease in Eastern Finnish Men. Atherosclerosis. 1988 Mar;70(1-2):155-60.

182. Alfthan G, Aro A, Arvilommi H, Huttunen JK. Selenium metabolism and platelet glutathione peroxidase activity in healthy Finnish men: effects of selenium yeast, selenite, and selenate. Am J Clin Nutr. 1991 Jan;53(1):120-5.

183. Mutanen M, Viita L, Mykkanen HM. Selenium supplementation does not alter platelet activation in subjects with normal selenium status. Int J Vitam Nutr Res. 1989;59(3):309-13.

184. Kivela SL, Maenpaa P, Nissinen A, Alfthan G, Punsar S, Enlund H, et al. Vitamin A, vitamin E and selenium status in an aged Finnish male population. Int J Vitam Nutr Res. 1989;59(4):373-80.

185. Korpela H, Kinnunen E, Juntunen J, Kumpulainen J, Koskenvuo M. Serum selenium concentration, glutathione peroxidase activity and lipid peroxides in a co-twin control study on multiple sclerosis. J Neurol Sci. 1989 Jun;91(1-2):79-84.

186. Korpela $\mathrm{H}$, Nuutinen LS, Kumpulainen J. Low serum selenium and glutathione peroxidase activity in patients receiving short-term total parenteral nutrition. Int J Vitam Nutr Res. 1989;59(1):80-4.

187. Valimaki M, Alfthan G, Pikkarainen J, Ylikahri R, Salaspuro M. Blood and liver selenium concentrations in patients with liver diseases. Clin Chim Acta. 1987 Jul 15;166(2-3):171-6.

188. Sundstrom H, Ylikorkala O, Kauppila A. Serum selenium and thromboxane in patients with gynaecological cancer. Carcinogenesis. 1986 Jul;7(7):1051-2.

189. Whanger PD, Beilstein MA, Thomson CD, Robinson MF, Howe M. Blood Selenium and GlutathionePeroxidase Activity of Populations in New-Zealand, Oregon, and South-Dakota. Faseb J. 1988 Nov;2(14):2996-3002.

190. Thomson CD. Assessment of requirements for selenium and adequacy of selenium status: a review. Eur J Clin Nutr. 2004;58(3):391-402.

191. Sluis KB, Darlow BA, George PM, Mogridge N, Dolamore BA, Winterbourn CC. Selenium and glutathione peroxidase levels in premature infants in a low selenium community (Christchurch, New Zealand)1992. 
192. Thomson CD, Steven SM, van Rij AM, Wade CR, Robinson MF. Selenium and vitamin E supplementation: activities of glutathione peroxidase in human tissues. Am J Clin Nutr. 1988 Aug;48(2):31623.

193. Butler JA, Thomson CD, Whanger PD, Robinson MF. Selenium distribution in blood fractions of New Zealand women taking organic or inorganic selenium. Am J Clin Nutr. 1991 Mar;53(3):748-54.

194. Robinson MF, Thomson CD, Jenkinson CP, Luzhen G, Whanger PD. Long-term supplementation with selenate and selenomethionine: urinary excretion by New Zealand women. Br J Nutr. 1997 Apr;77(4):55163.

195. Duffield AJ, Thomson CD. A comparison of methods of assessment of dietary selenium intakes in Otago, New Zealand. Br J Nutr. 1999 Aug;82(2):131-8.

196. Paterson E. Selenium, oxidant stress and smoking: University of Otago; 2000.

197. Thomson BM, Vannoort RW, Haslemore RM. Dietary exposure and trends of exposure to nutrient elements iodine, iron, selenium and sodium from the 2003-4 New Zealand Total Diet Survey. Br J Nutr. 2008 Mar;99(3):614-25.

198. New Zealand Health Information Service. Report on Maternity: Maternal and Newborn Information 2004. Wellington: Ministry of Health; 2007.

199. New Zealand Health Information Service. Report on Maternity: Maternal and Newborn Information 2003. Wellington: Ministry of Health; 2006.

200. New Zealand Health Information Service. Report on Maternity: Maternal and Newborn Information 2000 and 2001. Wellington: Ministry of Health; 2003.

201. New Zealand Health Information Service. Report on Maternity: Maternal and Newborn Information 2002. Wellington: Ministry of Health; 2004.

202. New Zealand Health Information Service. Report on Maternity: Maternal and Newborn Information 1999. Wellington: Ministry of Health; 2001.

203. Trogstad LI, Eskild A, Magnus P, Samuelsen SO, Nesheim BI. Changing paternity and time since last pregnancy; the impact on pre-eclampsia risk. A study of 547238 women with and without previous preeclampsia. Int J Epidemiol. 2001 Dec;30(6):1317-22.

204. Skjaerven R, Wilcox AJ, Lie RT. The interval between pregnancies and the risk of preeclampsia. New England Journal of Medicine. 2002 Jan 3;346(1):33-8.

205. Meltzer HM, Bibow K, Paulsen IT, Mundal HH, Norheim G, Holm H. Different Bioavailability in Humans of Wheat and Fish Selenium as Measured by Blood-Platelet Response to Increased Dietary Se. Biological Trace Element Research. 1993 Mar;36(3):229-41.

206. Meltzer HM, Norheim G, Loken EB, Holm H. Supplementation with Wheat Selenium Induces a DoseDependent Response in Serum and Urine of a Se-Replete Population. British Journal of Nutrition. 1992 Mar;67(2):287-94.

207. Saeed K, Thomassen Y, Langmyhr FJ. Direct Electro-Thermal Atomic-Absorption Spectrometric Determination of Selenium in Serum. Anal Chim Acta. 1979;110(2):285-9.

208. Meltzer HM, Haug E. Oral Intake of Selenium Has No Effect on the Serum Concentrations of Growth-Hormone, Insulin-Like Growth-Factor-I, Insulin-Like Growth Factor-Binding Protein-1 and Protein-3 in Healthy Women. Eur J Clin Chem Clin. 1995 Jul;33(7):411-5.

209. Karlsson J, Lundgren G, Ronneberg R. Plasma selenium in healthy man before and after nutratherapy. Int J Vitam Nutr Res. 1997;67(1):27-33.

210. Ringstad J, Aaseth J, Johnsen K, Utsi E, Thomassen Y. High serum selenium concentrations in reindeer breeding Lappish men. Arctic Med Res. 1991 Jul;50(3):103-6.

211. Ringstad J, Jacobsen BK, Thomassen Y, Thelle DS. The Tromso Heart Study: serum selenium and risk of myocardial infarction a nested case-control study. J Epidemiol Community Health. 1987 Dec;41(4):32932.

212. Ringstad J, Jacobsen BK, Tretli S, Thomassen Y. Serum selenium concentration associated with risk of cancer. J Clin Pathol. 1988 Apr;41(4):454-7.

213. Ringstad J, Kildebo S, Thomassen Y. Serum Selenium, Copper, and Zinc Concentrations in CrohnsDisease and Ulcerative-Colitis. Scand J Gastroentero. 1993 Jul;28(7):605-8. 
214. Ringstad J, Knutsen SF, Nilssen OR, Thomassen Y. A Comparative-Study of Serum Selenium and Vitamin-E Levels in a Population of Male Risk Drinkers and Abstainers - a Population-Based Matched-Pair Study. Biological Trace Element Research. 1993 Jan;36(1):65-71.

215. Gissel-Nielsen G. Effects of selenium supplementation of field crops. Frankenberger W, Engberg, RA, , editor. New York: Marcel Dekker; 1998.

216. Thompson JN, Erdody P, Smith DC. Selenium content of food consumed by Canadians. J Nutr. 1975 Mar;105(3):274-7.

217. Becker T, Vermeulen MJ, Wyatt PR, Meier C, Ray JG. Prepregnancy Diabetes and Risk of Placental Vascular Disease. Diabetes Care. 2007 October 2007;30(10):2496-8.

218. Gibson RS, Martinez OB, MacDonald AC. The Zinc, Copper, and Selenium Status of a Selected Sample of Canadian Elderly Women. Journal of Gerontology. 1985 May 1, 1985;40(3):296-302.

219. Lemoyne M, Van Gossum A, Kurian R, Jeejeebhoy K. Plasma vitamin E and selenium and breath pentane in home parenteral nutrition patients. Am J Clin Nutr. 1988 November 1, 1988;48(5):1310-5.

220. Allard JP, Aghdassi E, Chau J, Salit I, Walmsley S. Oxidative stress and plasma antioxidant micronutrients in humans with HIV infection. Am J Clin Nutr. 1998 Jan;67(1):143-7.

221. Funai EF, Paltiel OB, Malaspina D, Friedlander Y, Deutsch L, Harlap S. Risk factors for pre-eclampsia in nulliparous and parous women: the Jerusalem perinatal study. Paediatr Perinat Epidemiol. 2005 Jan;19(1):59-68.

222. Chaitchik S, Shenberg C, Nir-El Y, Mantel M. The distribution of selenium in human blood samples of Israeli population--comparison between normal and breast cancer cases. Biol Trace Elem Res. 1988 JanApr;15:205-12.

223. Tan KH, Kwek K, Yeo GS. Epidemiology of pre-eclampsia and eclampsia at the KK Women's and Children's Hospital, Singapore. Singapore Med J. 2006 Jan;47(1):48-53.

224. Hughes K, Chua LH, Ong CN. Serum selenium in the general population of Singapore, 1993 to 1995. Ann Acad Med Singapore. 1998 Jul;27(4):520-3.

225. Hughes K, Ong CN. Vitamins, selenium, iron, and coronary heart disease risk in Indians, Malays, and Chinese in Singapore. J Epidemiol Community Health. 1998 Mar;52(3):181-5.

226. Zareian Z. Hypertensive disorders of pregnancy. International Journal of Gynecology \& Obstetrics. 2004 Nov;87(2):194-8.

227. National Birthday Trust Fund London., Chamberlain R, Royal College of Obstetricians and Gynaecologists (Great Britain). British births 1970 : a survey under the joint auspices of the National Birthday Trust Fund and the Royal College of Obstetricians and Gynaecologists. London: Heinemann Medical; 1975.

228. Thorn J, Robertson J, Buss DH, Bunton NG. Trace nutrients. Selenium in British food. Br J Nutr. 1978 Mar;39(2):391-6.

229. Diplock A. Trace elements in human health with special reference to selenium. Am J Clin Nutr. 1987 May 1, 1987;45(5):1313-22.

230. Lloyd B, Lloyd RS, Clayton BE. Effect of Smoking, Alcohol, and Other Factors on the Selenium Status of a Healthy Population. Journal of Epidemiology and Community Health. 1983;37(3):213-7.

231. Foote JW, Hinks LJ, Lloyd B. Reduced Plasma and White Blood-Cell Selenium Levels in HemodialysisPatients. Clin Chim Acta. 1987 May 15;164(3):323-8.

232. Hinks LJ, Inwards KD, Lloyd B, Clayton B. Reduced Concentrations of Selenium in Mild CrohnsDisease. J Clin Pathol. 1988 Feb;41(2):198-201.

233. Tanner AR, Bantock I, Hinks L, Lloyd B, Turner NR, Wright R. Depressed selenium and vitamin E levels in an alcoholic population. Possible relationship to hepatic injury through increased lipid peroxidation. Dig Dis Sci. 1986 Dec;31(12):1307-12.

234. Damyanova AA, Akanle OB, Spyrou NM. Changes in the Elemental Content of Blood Components by Selenium Supplement in Humans. J Radioan Nucl Ch Ar. 1987 Jul;113(2):431-6.

235. Wolf M, Hubel CA, Lam C, Sampson M, Ecker JL, Ness RB, et al. Preeclampsia and future cardiovascular disease: potential role of altered angiogenesis and insulin resistance. J Clin Endocrinol Metab. 2004 Dec;89(12):6239-43.

236. Wolf M, Shah A, Jimenez-Kimble R, Sauk J, Ecker JL, Thadhani R. Differential Risk of Hypertensive Disorders of Pregnancy among Hispanic Women. J Am Soc Nephrol. 2004 May 1, 2004;15(5):1330-8. 
237. Chan JM, Oh WK, Xie W, Regan MM, Stampfer MJ, King IB, et al. Plasma Selenium, Manganese Superoxide Dismutase, and Intermediate- or High-Risk Prostate Cancer. Journal of Clinical Oncology. 2009 August 1, 2009;27(22):3577-83.

238. Kumar R, Yu Y, Story RE, Pongracic JA, Gupta R, Pearson C, et al. Prematurity, chorioamnionitis, and the development of recurrent wheezing: A prospective birth cohort study. Journal of Allergy and Clinical Immunology. [doi: DOI: 10.1016/j.jaci.2008.01.030]. 2008;121(4):878-84.e6.

239. Yoneyama S, Miura K, Itai K, Yoshita K, Nakagawa H, Shimmura T, et al. Dietary intake and urinary excretion of selenium in the Japanese adult population: the INTERMAP Study Japan. European Journal of Clinical Nutrition. 2008 Oct;62(10):1187-93.

240. Miyazaki $\mathrm{Y}$, Koyama H, Nojiri M, Suzuki S. Relationship of dietary intake of fish and non-fish selenium to serum lipids in Japanese rural coastal community. J Trace Elem Med Biol. 2002;16(2):83-90.

241. Miyazaki Y, Koyama H, Sasada Y, Satoh H, Nojiri M, Suzuki S. Dietary habits and selenium intake of residents in mountain and coastal communities in Japan. J Nutr Sci Vitaminol (Tokyo). 2004 Oct;50(5):30919.

242. Furuhashi N, Suzuki M, Kono H, Tanaka M, Takahashi T, Hiruta M. Clinical Background of PreEclampsia in Japanese Women. Clin Exp Hypertens B. 1982;1(4):505-10.

243. Suzuki S, Igarashi M. Risk factors for preeclampsia in Japanese twin pregnancies: comparison with those in singleton pregnancies. Archives of Gynecology and Obstetrics. 2009 Sep;280(3):389-93.

244. Taghavi M, Saghafi N, Shirin S. Outcome of thyroid dysfunction in pregnancy in Mashhad, Iran. International Journal of Endocrinology and Metabolism. 2009;7(2):82-5.

245. Tara F, Rayman MP, Boskabadi H, Ghayour-Mobarhan M, Sahebkar A, Yazarlu O, et al. Selenium supplementation and premature (pre-labour) rupture of membranes: a randomised double-blind placebocontrolled trial. J Obstet Gynaecol. 2010 Jan;30(1):30-4.

246. Tara F, Maamouri G, Rayman MP, Ghayour-Mobarhan M, Sahebkar A, Yazarlu O, et al. Selenium Supplementation and the Incidence of Preeclampsia in Pregnant Iranian Women: A Randomized, DoubleBlind, Placebo-Controlled Pilot Trial. Taiwanese Journal of Obstetrics and Gynecology. [doi: DOI: 10.1016/S1028-4559(10)60038-1]. 2010;49(2):181-7.

247. Mokhber N, Namjoo M, Tara F, Boskabadi H, Rayman MP, Ghayour-Mobarhan M, et al. Effect of supplementation with selenium on postpartum depression: a randomized double-blind placebo-controlled trial. J Matern Fetal Neonatal Med. 2011 Jan;24(1):104-8.

248. Xiong X, Demianczuk N, Saunders L, Wang F, Fraser W. Impact of preeclampsia and gestational hypertension on birth weight by gestational age. Am J Epidemiol. 2002;155:203 - 9.

249. Bresee K. Potential Human Health Impacts Related to Selenium in fish from the North Saskatchewan River. Calgary, Alberta: Intrinsik Environmental Sciences Inc.2009. p. 1-21.

250. Kahn SR, Platt R, McNamara H, Rozen R, Chen MF, Genest J, et al. Inherited thrombophilia and preeclampsia within a multicenter cohort: the Montreal Preeclampsia Study. American Journal of Obstetrics and Gynecology. 2009 Feb;200(2):-.

251. McDermid JM, Lalonde RG, Gray-Donald K, Baruchel S, Kubow S. Associations between dietary antioxidant intake and oxidative stress in HIV-seropositive and HIV-seronegative men and women. J Acq Immun Def Synd. 2002 Feb 1;29(2):158-64.

252. Vézina $D$, Mauffette $F$, Roberts $K$, Bleau G. Selenium-vitamin E supplementation in infertile men. Biological Trace Element Research. 1996;53(1):65-83.

253. Krittaphol W, Bailey KB, Pongcharoen T, Winichagoon P, Thomson C, Gibson RS. Primary school children from northeast Thailand are not at risk of selenium deficiency. Asia Pac J Clin Nutr. 2006;15(4):47481.

254. Mahaisiriyodom A, Viroonudomphol D. Serum zinc, selenium and copper in priest subjects. J Med Assoc Thai. 2008;91 Suppl 1:S145-50.

255. Lee CJ, Hsieh TT, Chiu TH, Chen KC, Lo LM, Hung TH. Risk factors for pre-eclampsia in an Asian population. Int J Gynaecol Obstet. 2000 Sep;70(3):327-33.

256. Chen CK, Liaw JM, Juang JG, Lin TH. Antioxidant enzymes and trace elements in hemodialyzed patients. Biol Trace Elem Res. 1997 Jul-Aug;58(1-2):149-57.

257. Chen CJ, Lai JS, Wu CC, Lin TS. Serum selenium in adult Taiwanese. Science of The Total Environment. 2006 Aug 15;367(1):448-50. 
258. Vanderlelie J, Venardos K, Perkins AV. Selenium deficiency as a model of experimental preeclampsia in rats. Reproduction. 2004 November 1, 2004;128(5):635-41.

259. Anderson PH, Berrett S, Patterson DS. Glutathione peroxidase activity in erythrocytes and muscle of cattle and sheep and its relationship to selenium. J Comp Pathol. 1978 Apr;88(2):181-9.

260. Perona G, Cellerino R, Guidi GC, Moschini G, Stievano BM, Tregnaghi C. Erythrocytic glutathione peroxidase: its relationship to plasma selenium in man. Scand J Haematol. 1977 Jul;19(1):116-20.

261. Reilly PC. Selenium supplementation - the Finnish experiment. Nutrition Bulletin. 1996;21(3):16773.

262. Wang WC, Makela AL, Nanto V, Makela P, Lagstrom H. The serum selenium concentrations in children and young adults: a long-term study during the Finnish selenium fertilization programme. Eur J Clin Nutr. 1998 Jul;52(7):529-35.

263. Reilly C. Selenium in food and health. London; New York: Blackie Academic \& Professional; 1996.

264. Behne D, Weiler H, Kyriakopoulos A. Effects of selenium deficiency on testicular morphology and function in rats. J Reprod Fertil. 1996 Mar;106(2):291-7.

265. Underwood EJ. Trace elements in human and animal nutrition. 4th ed. New York: Academic Press; 1977.

266. Xia Y, Hill KE, Byrne DW, Xu J, Burk RF. Effectiveness of selenium supplements in a low-selenium area of China. The American Journal of Clinical Nutrition. 2005 April 1, 2005;81(4):829-34.

267. Duffield AJ, Thomson CD, Hill KE, Williams S. An estimation of selenium requirements for New Zealanders. Am J Clin Nutr. 1999 Nov;70(5):896-903.

268. Monsen ER. Dietary Reference intakes for the antioxidant nutrients: Vitamin C, vitamin E, selenium, and carotenoids (vol 100, pg 638, 2000). J Am Diet Assoc. 2000 Sep;100(9):1008-9.

269. Dietary reference values for food energy and nutrients for the United Kingdom. Report of the Panel on Dietary Reference Values of the Committee on Medical Aspects of Food Policy. Rep Health Soc Subj (Lond). 1991;41:1-210.

270. [Anon]. Nutrient reference values for Australia and New Zealand. Food Aust. 2006 Jul;58(7):298-.

271. Neve J. New indices for assessment of trace element status and requirement, with a special focus on selenium. Trace Elements in Man and Animals 10. 2000:317-22

1172.

272. Zachara BA, Pawluk H, Bloch-Boguslawska E, Sliwka KM, Korenkiewicz J, Skok Z, et al. Tissue level, distribution, and total body selenium content in healthy and diseased humans in Poland. Arch Environ Health. 2001 Sep-Oct;56(5):461-6.

273. Dorea JG. Selenium and breast-feeding. British Journal of Nutrition. 2002;88(05):443-61.

274. Combs GF, Jr. Selenium in global food systems. Br J Nutr. 2001 May;85(5):517-47.

275. Lu BY. [Changes in selenium in patients with pregnancy-induced hypertension]. Zhonghua Fu Chan Ke Za Zhi. 1990 Nov;25(6):325-7, 82.

276. Rosamond WD, Chambless LE, Folsom AR, Cooper LS, Conwill DE, Clegg L, et al. Trends in the Incidence of Myocardial Infarction and in Mortality Due to Coronary Heart Disease, 1987 to 1994. New England Journal of Medicine. 1998;339(13):861-7.

277. Savage L. Review of Swedish Cervical Cancer Screening Program Demonstrates Effectiveness and Room for Improvement. J Natl Cancer I. 2008 May 7, 2008;100(9):603.

278. Whanger P, Vendeland S, Park YC, Xia Y. Metabolism of subtoxic levels of selenium in animals and humans. Ann Clin Lab Sci. 1996 Mar-Apr;26(2):99-113.

279. World Health Organization., Food and Agriculture Organization of the United Nations., International Atomic Energy Agency. Trace elements in human nutrition and health. Geneva: World Health Organization; 1996.

280. Rayman MP. Dietary selenium: time to act. BMJ. 1997 Feb 8;314(7078):387-8.

281. Catov JM, Nohr EA, Bodnar LM, Knudson VK, Olsen SF, Olsen J. Association of Periconceptional Multivitamin Use With Reduced Risk of Preeclampsia Among Normal-Weight Women in the Danish National Birth Cohort. American Journal of Epidemiology. 2009 June 1, 2009;169(11):1304-11.

282. Rumiris D, Purwosunu Y, Wibowo N, Farina A, Sekizawa A. Lower Rate of Preeclampsia After Antioxidant Supplementation in Pregnant Women with Low Antioxidant Status. Hypertension in Pregnancy. 2006;25(3):241-53. 
283. Han L, Zhou SM. Selenium supplement in the prevention of pregnancy induced hypertension. Chin Med J (Engl). 1994 Nov;107(11):870-1.

284. Chappell LC, Seed PT, Kelly FJ, Briley A, Hunt BJ, Charnock-Jones DS, et al. Vitamin C and E supplementation in women at risk of preeclampsia is associated with changes in indices of oxidative stress and placental function. Am J Obstet Gynecol. 2002 Sep;187(3):777-84.

285. Roberts JM, Myatt L, Spong CY, Thom EA, Hauth JC, Leveno KJ, et al. Vitamins C and E to Prevent Complications of Pregnancy-Associated Hypertension. New England Journal of Medicine. 2010;362(14):1282-91.

286. Polyzos NP, Mauri D, Tsappi M, Tzioras S, Kamposioras K, Cortinovis I, et al. Combined vitamin C and $\mathrm{E}$ supplementation during pregnancy for preeclampsia prevention: a systematic review. Obstet Gynecol Surv. 2007 Mar;62(3):202-6.

287. Moses EK, Johnson MP, Tommerdal L, Forsmo S, Curran JE, Abraham LJ, et al. Genetic association of preeclampsia to the inflammatory response gene SEPS1. Am J Obstet Gynecol. 2008 Mar;198(3):336 e1-5.

288. Oxford Safer Pregnancy Alliance (OSPREY). SPRINT (Selenium in Pregnancy Intervention) trial. Oxford biomedical Research Centre, University of Oxford; 2009 [cited 201020 October ]; Available from: http://www.oxfordbrc.org/research/women-and-paediatrics/osprea/. 
Figure 1. Effect of plasma selenium concentration on the incidence of preeclampsia. Plot includes linear regression line with associated $95 \% \mathrm{CI}$ lines.

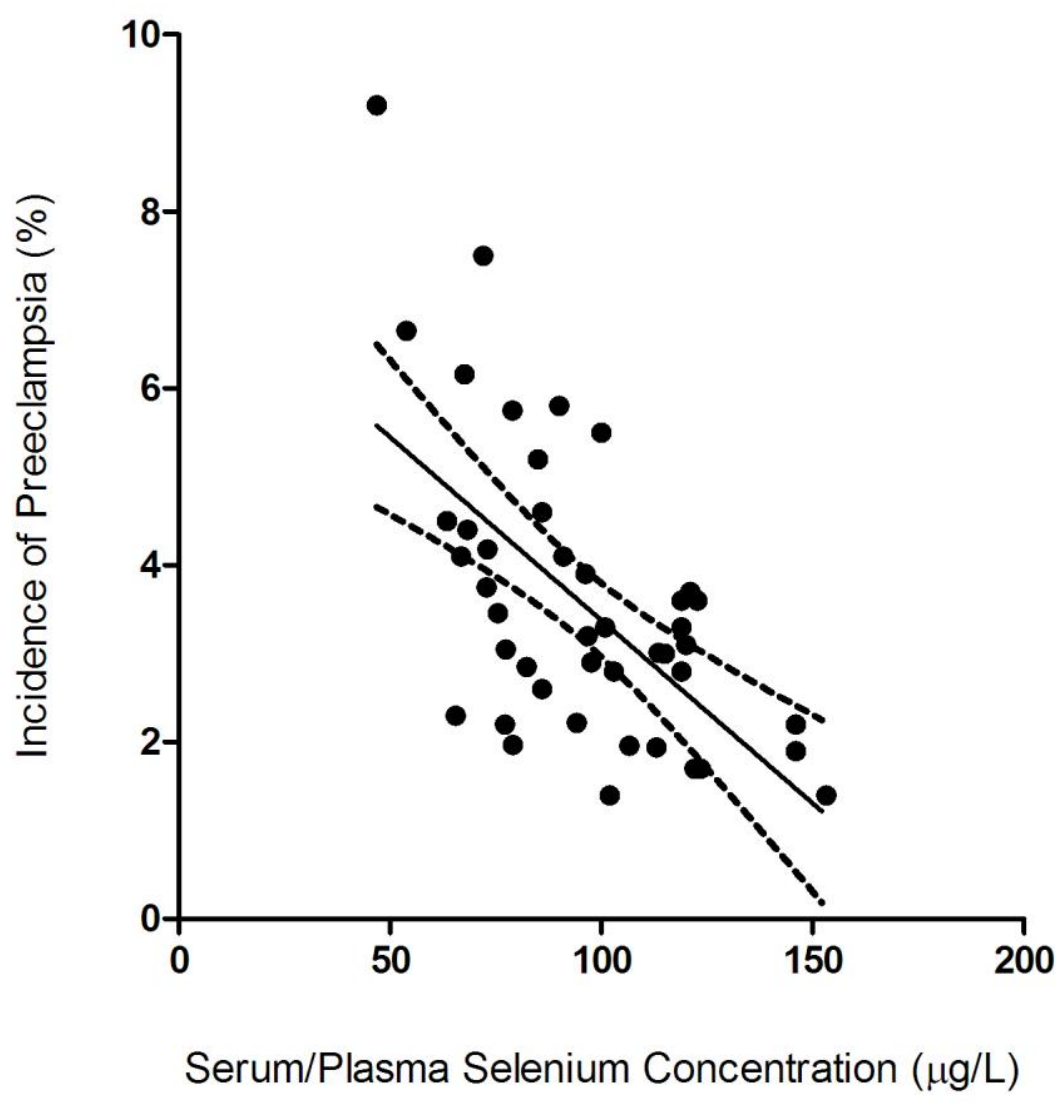

Figure 2. Comparison of the incidence of preeclampsia globally for countries split on the basis of selenium sufficiency. A selenium concentration of $95 \mathrm{ug} / \mathrm{L}$ was used as the point at which populations were considered Seleno-Deficient (23 published studies) or Seleno-Sufficent (20 published studies).

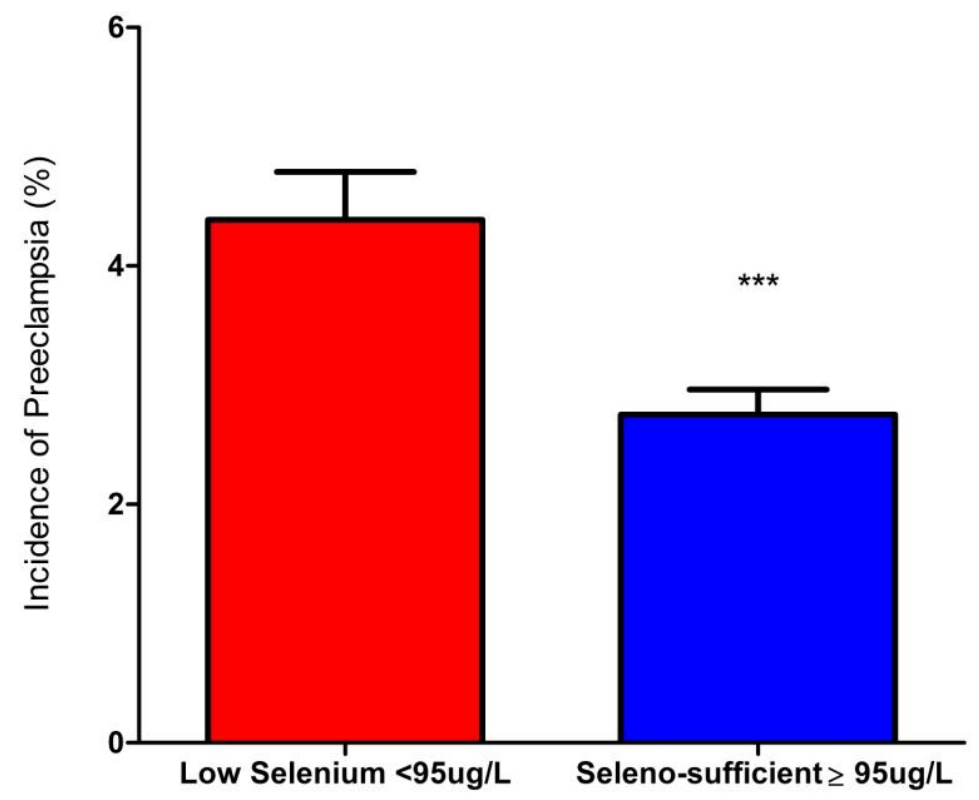

Serum/Plasma Selenium Concentration $(\mu \mathrm{g} / \mathrm{L})$ 
Figure 3. Comparison of the incidence of preeclampsia in the New Zealand and Finnish populations pre and post selenium supplementation.

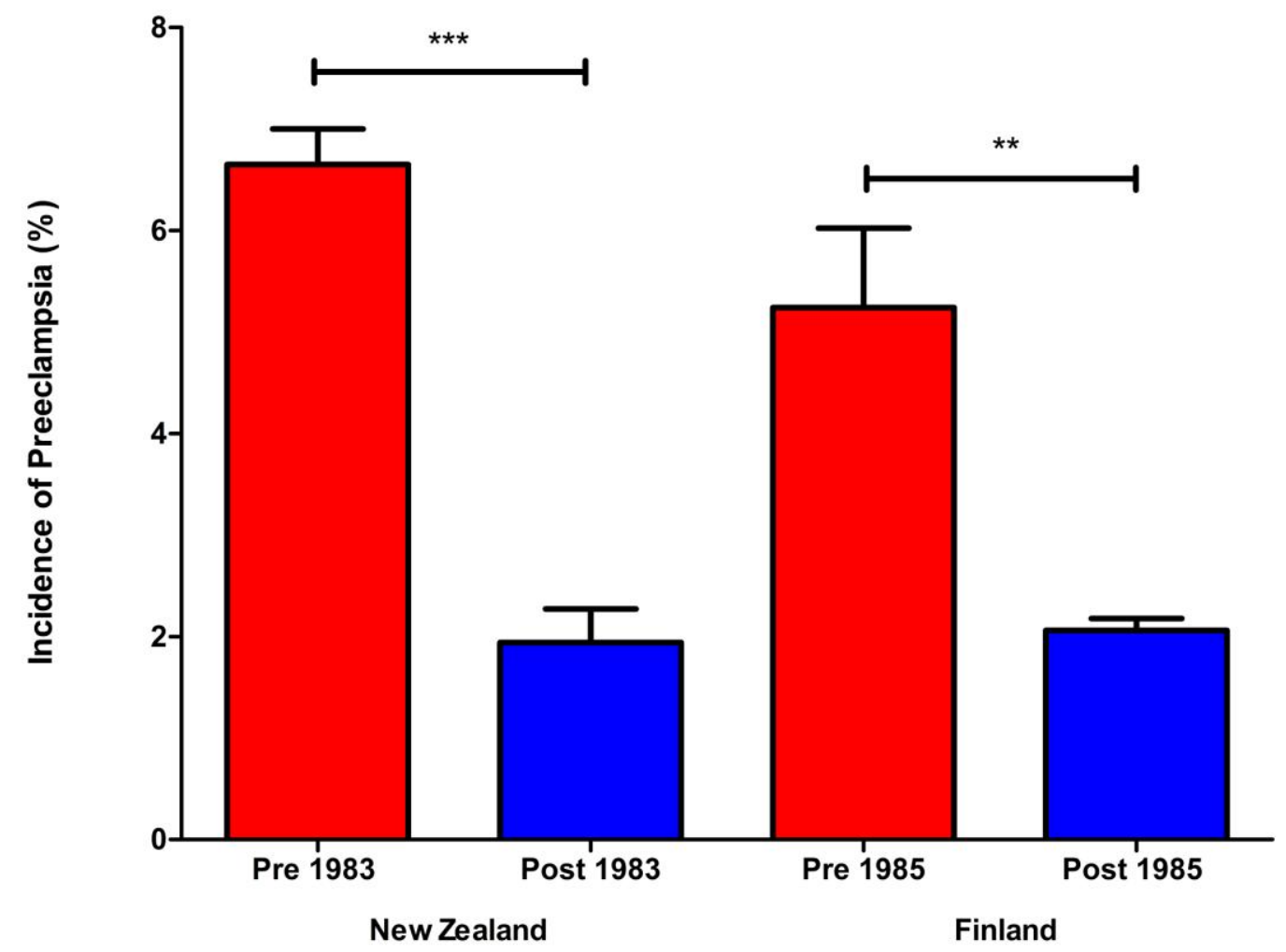

